\title{
Kalp Yetersizliği Hastalarında Ölüm Kaygısının Belirlenmesi
}

\author{
Betül Bayrak, @ Sıdıka Oğuz, @ Zozan Karabulut, $\odot$ Selman Çelik, $\odot$ Cemal Kodak
}

Marmara Üniversitesi Sağlık Bilimleri Fakültesi, İç Hastalıkları Hemşireliği Anabilim Dalı, İstanbul

\begin{abstract}
Özet
Amaç: Bu tanımlayıcı ve kesitsel çalışma, kalp yetersizliği (KY) hastalarında ölüm kaygısının belirlenmesi amacıyla yapıldı. Yöntemler: Araştırma, İstanbul'da bulunan iki eğitim ve araştırma hastanesinin kardiyoloji servislerinde Aralık 2018 Mayıs 2019 tarihleri arasında yatan 150 KY hastası ile yapıldı. Araştırma verilerinin elde edilmesinde "Anket Formu" ve "Thorson - Powel Ölüm Kaygısı Ölçeği" kullanıldı. Verilerin değerlendirilmesinde tanımlayıcı istatistikler, independent sample t testi ve One-way ANOVA testi kullanıldı.

Bulgular: Hastaların yaş ortalaması 66.53 \pm 9.07 olup \%55.3'ü erkektir. Hastaların \%38'inde diyabet, \%78.3'ünde hipertansiyon vardır. Hastaların \%34'ü NYHA evre 2 KY hastasıdır. Çalışmaya katılan hastaların Thorson-Powel Ölüm Kaygısı Ölçeğinden aldığı puan ortalaması $56.80 \pm 16.55$ olarak bulundu. 65 yaşın altındaki hastalarda, kadınlarda, lise mezunlarında, bekarlarda, geliri giderinden az olanlarda ölüm kaygısı yüksek ancak istatstiksel olarak anlamlı değildir ( $p>0.05$ ). NYHA sınıflamasına göre evre 4'teki KY hastalarında, çalışmayan hastalarda ve ölümü endişe uyandıran bir kavram olarak gören hastalarda ölüm kaygısı daha yüksek olup istatistiksel olarak anlamlıdır $(p<0.05)$.
\end{abstract}

Sonuç: Çalışmaya katılan hastalar ölüm kaygısını orta düzeyde yaşamaktadırlar. NYHA sınıflaması evre 4' teki hastalarda, çalışmayanlarda, ölümü endişe uyandıran bir kavram olarak gören hastalarda ölüm kaygısı artmaktadır.

Anahtar sözcükler: Hemşirelik; kalp yetersizliği; ölüm kaygısı.

\section{Determination of Death Anxiety in Heart Failure Patients}

\begin{abstract}
Objective: This descriptive and cross-sectional study was conducted to determine death anxiety in patients with heart failure (HF). Methods: The study was conducted with $150 \mathrm{HF}$ patients hospitalized in the cardiology departments of two training and research hospital in Istanbul between December 2018 and May 2019. Data were collected by using the Questionnaire and Thorson Powel Death Anxiety Scale. Descriptive statistics, independent sample t test and One-way ANOVA test were used to evaluate the data.

Results: The mean age of the patients was $66.53 \pm 9.07$ and $55.3 \%$ were male. $38 \%$ of the patients had diabetes and $78.3 \%$ had hypertension. 34\% of the participants were NYHA stage $2 \mathrm{HF}$ patients. The mean score obtained from Thorson-Powel Death Anxiety Scale was 56.80 16.55. Death anxiety in patients under 65 years, women, high school graduates, singles and underincome was high but not statistically significant ( $p>0.05$ ). Death anxiety scores was significantly higher in patients of NYHA stage $4 \mathrm{HF}$, patients who did not work and patients who considered death as a worrying concept ( $p>0.05)$.

Conclusion: The patients who participated in the study experienced moderate death anxiety. Death anxiety increases in patients of NYHA classification stage 4, patients who did not work and patients who saw death as a worrying concept.

Keywords: Death anxiety; heart failure; nursing.
\end{abstract}

Cite this article as: Bayrak B, Oğuz S, Karabulut Z, Çelik S, Kodak C. Determination of Death Anxiety in Heart Failure Patients. Turk J Cardiovasc Nurs 2019;10(23):97-104.

İletişim (Correspondence): Araş. Gör. Uzm. Betül Bayrak. Marmara Üniversitesi Sağlık Bilimleri Fakültesi, İ̧ Hastalıkları Hemşireliği Anabilim Dalı, İstanbul, Turkey

Telefon (Phone): +90 5393771786 E-Posta (E-mail): bayrak.betul@yahoo.com

Başvuru Tarihi (Submitted Date): 13.11.2019 Kabul Tarihi (Accepted Date): 06.12.2019

oCopyright 2019 by Turkish Society of Cardiology - Available online at www.anatoljcardiol.com 
$\mathrm{K}^{\mathrm{a} p}$ alp yetersizliği $(\mathrm{KY})$ yüksek mortalite ve morbidite oranarı ile insidansı artan bir hastalıktır. ${ }^{[1]}$ Kalp Yetersizliği, 65 yaşından büyük hastalar için hastaneye kabulün en sık nedenidir. Dünyada, yaşlanan bir popülasyonla ve KY hastalarında sağkalımı arttıran tıbbi gelişmelerin sonucunda KY ile yaşayan insan sayısı artmaya devam etmektedir. ${ }^{[1,2]}$

Artan uzun ömürlülüğün sonucunda $K Y$ hastaları zamanla daha büyük semptom yüküne maruz kalmaktadır. KY hastaları dispne, ödem, sıvı tutulumu ve pulmoner konjesyon gibi klasik semptomlara ek olarak ağrı, depresyon, gastrointestinal stres ve yorgunluk semptomlarını da sıklıkla yaşarlar. Semptom yönetimi, kapsamlı semptom değerlendirmesini ve semptomları hafifletmek için başarılı bir tedavi yaklaşımını kapsamalıdır. Başarılı tedavi, yalnızca fiziksel değil, duygusal, sosyal ve manevi yönleri de içermelidir. ${ }^{[3]} \mathrm{KY}$ hastaları, hastalığın ilerleyen evrelerinden itibaren ve özellikle yaşamın son altı ayında ortaya çıkan fiziksel, psikolojik, sosyal ve varoluşsal sorunlar yaşar. ${ }^{[4]}$ New York Kalp Birliği (NYHA) fonksiyonel sınıflamasının ileri derecelerindeki KY hastaları, ölüme yakın semptomlar yaşamaya başlar. [4] Ölüme yakınlık beraberinde korku ve kaygıyı artırır, bunun sonucunda yaşam kalitesini ve ağırlaşan semptomlara karşı toleransı azaltır. ${ }^{[2,5,6]}$ Kaygı, sıkıntı, korku ve güçsüzlük duygusu da dahil olmak üzere ölümle ilgili farkındalık ve bilişe neden olan tutuma, genellikle ölüm kaygısı/korkusu denir. Ölüm kaygısı fiziksel rahatsızlığın ilerlemesine neden olabilir, uyumsuz biliş modellerine yol açar ve umutsuzluk, güçsüzlük, korku ve kontrol kaybı duyguları içeren çok fazla stres yaratır. Bu durum, ölüm kaygısı ve diğer zihinsel bozukluklar arasındaki korelasyonun göreceli olarak yüksek olmasının nedenini açıklamaktadır. ${ }^{[7]}$ KY hastalarında kaygının artması, yaşamın sonunun geldiği düşüncesi ile ölüm anksiyetesi sonucu deprosyona yatkınlık artar. Depresyon KY hastalarında sıklıkla karşılaşılan bir tablodur ve bu hastaların \%70'inde görülen bir duygu durum bozukluğudur. KY'de depresyon önceden varolan semptomlara duyarlılığı artırır, öz bakım ile etkileşip tedaviye uyumu bozar ve mortalite oranını beş kat arttırır. ${ }^{[6]}$ Depresyon ve kötüleşen KY arasındaki bağlantıyı açıklayan mekanizmalar arasında, artmış kortizol seviyeleri, daha yüksek trombosit agregasyonu oranları ve proenflamatuar bir ortamın geliştirilmesi gibi artmış bir sempatik ton ve/veya inhibe edilmiş parasempatik ton bulunmaktadır. ${ }^{[8]} \mathrm{Bu}$ etkilere bağlı olarak depresyonun KY hastalarında semptomların sık yaşanmaya başlaması, hastaneye yatışların tekrarlanması, ölüm ve sağlık maliyetlerinin artması gibi kötü sonuçları vardır. ${ }^{[2]} \mathrm{KY}$ 'de depesyondan sonra en sık karşılaşılan bir diğer psikososyal sorun anksiyetedir. ${ }^{[9,10]}$ KY hastalarının \%13'ünün anksiyete bozukluğu tanı kriterlerini karşıladığı bildirilmektedir ve yaklaşık \%30'unda anksiyete tanısı mevcuttur. ${ }^{[9]}$ Anksiyete bozukluğu da depresyon gibi aynı sorunlara neden olabilir ancak depresyon kadar mortaliteyi büyük oranda etkilemediği söylenmektedir. ${ }^{[10]}$

KY fiziksel durumun yanı sıra ruhsal boyutları ile ele alınması gereken çok boyutlu bir hastalık olması nedeni ile semptoma yönelik tıbbi tedavinin yanı sıra psikososyal sorunların da ele alındığı bir tıbbi bakım yönetimi planı çizilmelidir. Klinikte bu hastaların nasıl değerlendirileceğinin bilinmemesi, kalp-beyin etkileşiminin değerlendirilmemesi, sağlık profesyonellerinin bu konuya karşı ilgisiz olmalarından kaynaklanmaktadır. ${ }^{[10]}$ Depresyon ve anksiyete tedavi sürecini olumsuz yönde etkileyen tanı konulması zor ${ }^{[10,11]}$ ancak tedavisi kolay ruhsal sorunlardır. KY hastalarında depresyon ve anksiyeteye neden olan etkenler arasında başkalarına bağımlı hale gelme endişesi, ${ }^{[11]}$ kullanılan ilaçlar, fiziksel engeller, ekonomik sorunlar, hastalık algısı, beden imgesinde bozulma ve ölüm korkusu yer almaktadır. ${ }^{[10]}$

Literatürde KY hastalarında depresyon ve anksiyete bozukluğunu araştıran bir çok çalışma vardır. Ancak KY hastalarında bu psikosoyal duygu durum bozukluklarının temelinde yatan etken olan ölüm kaygısını inceleyen herhangi bir çaIışmaya rastlanmamıştır.

KY ilerleyen evrelerinde artan semptom yükü ve hastayı eksik (sadece fiziksel) değerlendirmenin bir sonucu olarak hastaneye tekrarlı yatışların sık görülmesi nedeni ile hastalar tarafından ölüm riski yüksek bir hastalık olarak algılanmaktadır. Ölüm karşısında hastaların bazıları umutsuzluk veya korku hissedebilir ve kabullenmeyip ölüme karşı çıkabilir, bazı hastalar ise ölümü yaşamın doğal bir parçası olarak görebilir. ${ }^{[12]}$ Ölüm kaygısının kişilik özelliklerinin bir özelliğini yansıtabileceğini ve bu nedenle zaman içinde göreceli olarak sabit kalabileceği öngörülmektedir. ${ }^{[12]}$ Ölüm kaygısı eğer kişilik özelliklerini yansıtan bir olgu ise zaman içinde değişmez bir durum olacağından hastalığın erken dönemlerinde tanınması, etkileyen faktörlerin ortaya konması ileri dönemlerde gelişebilecek psikososyal sorunların tanımlanması için önemli veriler sağlayabilir. Hastalığın seyrini ve prognozunu çok büyük ölçüde etkileyen depresyon veya anksiyete gibi psikososyal sorunların önüne geçebilmenin temelinde kapsamlı ve bütüncül hasta değerlendirmesi vardır. Bu sorunların temelinde yatan ve bir kişilik özelliği olarak bilinen ölüm kaygısının KY hastalarında incelenmemesi literatürde önemli bir boşluktur. Bu nedenle, bu araştırma KY hastalarında ölüm kaygısı ve ölüm kaygısına KY hastalığı semptomları dışında etkileyen diğer sosyodemografik özelliklerin neler olduğunun incelenmesi amacıyla planlanmıştır. Bu araştırmanın sonuçları, KY hasta- 
larında ölüm kaygısının düzeyi ve ölüm kaygısını etkileyen faktörlerin belirlenmesi ile ilgili bulguları içermektedir. Bu bulgular, ileride yapılacak çalışmalar için literatüre önemli katkı sağlayacaktır.

\section{Gereç ve Yöntem}

Araştırmanın tipi: Bu araştırmanın tasarımı tanımlayıcı ve kesitseldir.

Araştırmanın yapıldığı yer ve zaman: Bu araştırma İstanbul'da bulunan iki eğitim ve araştırma hastanesinin kardiyoloji servislerinde yatan KY hastaları ile Aralık 2018-Mayıs 2019 tarihleri arasında yürütüldü.

Araştırmanın Evreni ve Örneklemi: Araştırmanın evrenini araştırmanın yapıldığı zaman aralıklarında kurum izni alınan hastanelerin kardiyoloji servislerinde yatan ve polikliniklerinde ayaktan hizmet alan çalışmaya alınma kriterlerine uyan tüm KY hastaları oluşturmaktadır. Araştırmanın örneklemini, iletişim sorunu olmayan, 18 yaşından büyük, çalışmaya katılmayı kabul eden ve an az bir yıl önce KY tanısı almış $150 \mathrm{KY}$ hastası oluşturmaktadır. Araştırmaya katılma kriterlerine uymayan, araştırmaya katılma kriterlerine uyan fakat psikiyatrik sorunu olan, böbrek yetersizliği tanısı olup diyalize giren ve kemoterapi veya radyoterapi tedavisi alan kanser hastaları ölüm kaygısı puanlarını etkileyebileceği için çalışmaya dahil edilmedi. Araştırma örneklemi G* power 3.1.9.2 programı ile $\alpha=0.05$, etki büyüklüğü $=0.30$ ve çalışmanın gücü \%95 alındığında 121 olarak hesaplanmıştır, bu değerin \%20'den biraz fazlası alındığında örneklem sayısı 150 olarak belirlendi.

Veri Toplama Araçları: Araştırma verilerinin elde edilmesinde KY olan hastaların sosyo-demografik özelliklerini içeren anket formu ve Thorson - Powell Ölüm Kaygısı Ölçeği kullanıldı. Anket formu araştırmacılar tarafından hazırlanmış olup; yaş, cinsiyet, eğitim durumu, çalışma durumu, ilk kalp yetersizliği tanısının konulma zamanı, düzenli ilaç kullanımı, sigara kullanımı, alkol kullanımı, fiziksel ve ruhsal sağlık algısı, ölüm kavramının kişi için ne ifade ettiği, kalp yetersizliği tanısı almadan önce böyle bir kaygının olup olmadığı ve kişide bu kaygının oluşmasına sebep olan etkenin ne olduğu gibi sorular yer almaktadır.

Thorson-Powell Ölüm Kaygısı Ölçeği (TP DAS) 1992 yılında Thorson ve Powell tarafından geliştirilmiştir. ${ }^{[13]}$ Yıldız ve Karaca (2001) tarafından Türkçeye uyarlaması yapılmıştır. ${ }^{[14]}$ Ölçek 17 'si olumlu, 8 'i olumsuz olmak üzere 25 maddeden oluşmaktadır. Her bir madde için puanlama $5^{\prime}$ li likert tipinde yapılmaktadır. Likert tipi ölçek için 0 puan "Fikrime çok uygun" 4 puan "Fikrime Çok Aykırı" anlamına gelmektedir. Olumsuz ifadelerde Likert ölçeği 4'ten 0'a tersine çevrilir.
Toplam puan minimum 0 ve maksimum 100 olabilir. Puanlama sisteminde ise en düşük puan 0 ve en yüksek puan 100 dür. Alınan puanların yüksek olması ölüm kaygısının yüksek olduğunu gösterirken, düşük puanlar ise ölüm kaygısının düşük olduğunu gösterir. Araştırmalarda kaygıyı ölçmek için geçerli ve güvenilir bir araç olduğu tespit edilmiştir. Ölçek Cronbach's alfa katsayısı 0.84 olarak bulunmuştur. ${ }^{[14]}$

Veri Toplama Araçlarının Uygulanması: Araştırmaya başlamadan önce bir üniversitenin Sağlık Bilimleri Enstitüsü'nden etik kurul onayı alındı (17.12.2018-235). Etik kurul onayı alındıktan sonra uygulamanın yapılacağı hastanelerden kurum izni alındı. Kurum izni alınan hastanelerin kardiyoloji kliniklerinde yatan ve polikliniklerinde ayaktan tedavi gören KY olan hastalara araştırma hakkında detaylı bilgi verildikten ve çalışmaya katılmayı kabul eden hastaların yazılı ve sözlü onamları alındıktan sonra Anket Formu ve Thorson-Powell Ölüm Kaygısı Ölçeği (TP DAS) yüz yüze görüşülerek dolduruldu. Verilerin araştırmacılar tarafından doldurulması her bir hasta için 25-30 dk. sürdü.

Verilerin İstatistiksel Analizi: Araştırmadan elde edilen veriler SPSS (Statistical Package for Social Sciencess) paket programı kullanılarak değerlendirildi. Değerlendirmede tanımlayıcı istatistikler (sayı, yüzde, ortalama ve standart sapma) ve bağımlı değişken olan Thorson - Powel Ölüm Kaygısı Ölçeği puanlarının bağımsız değişkenler ile karşılaştırılmasında bağımsız iki grup arasındaki niceliksel sürekli verilerin karşılaştırılmasında kullanılan İndependent Sample t testi, ikiden fazla bağımsız grup arasındaki niceliksel sürekli verilerin değerlendirilmesinde ise tek yönlü (One Way) Anova testi kullanıldı. Anova testi sonrasında farklılıkları belirlemek üzere tamamlayıcı Post-hoc analizi kullanıldı. Elde edilen bulgular $\mathrm{p}<0.05$ anlamlılık düzeyinde değerlendirildi.

\section{Kalp Yetersizliği Hastalarının Sosyodemografik Özellikleri ve Thorson-Powell Ölüm Kaygısı Ölçeği Puanlarının Karşılaştırılması}

Araştırmamıza katılan KY hastalarının yaş ortalaması $66.53 \pm 9.072$ olup büyük çoğunluğunu (\%60.6) 65 ve üstü yaş grubundaki hastalar oluşturmaktadır. Hastaların yarısından fazlası (\%55.3) erkektir ve büyük bir bölümünün (\%62.7) eğitim seviyesi ilköğretim düzeyindedir. Hastaların $\% 90$ 'ının evli olduğu ve \%55.3'ünün gelir seviyesinin giderine eşit olduğu bulundu. KY yetersizliği hastalığına ait bulgulara bakıldığında hastalık süre $5.01 \pm 3.92$ yıl olarak bulundu. New York Kalp Birliği (NYHA) fonksiyonel sınıflaması evrelerine göre hastaların \%34'ü Evre 2, \%31.3'ü ise Evre 3 KY hastası olduğu tespit edildi (Tablo 1). Hastaların 


\begin{tabular}{|c|c|c|c|c|c|}
\hline & $\mathbf{n}$ & $\%$ & TP DAS puanı & Test değeri & $\mathbf{p}$ \\
\hline \multicolumn{6}{|l|}{ Yaş (66.53 \pm 9.072$)$} \\
\hline 65 altı & 59 & 39.4 & $61.41 \pm 13.12$ & $-0.186^{*}$ & 0.853 \\
\hline 65 ve üstü & 91 & 60.6 & $55.42 \pm 17.04$ & & \\
\hline \multicolumn{6}{|l|}{ Cinsiyet } \\
\hline Kadın & 67 & 44.7 & $56.91 \pm 14.76$ & $0.738^{*}$ & 0.86 \\
\hline Erkek & 83 & 55.3 & $56.70 \pm 17.90$ & & \\
\hline \multicolumn{6}{|l|}{ Eğitim durumu } \\
\hline Okuryazar değil & 32 & 21.3 & $56.84 \pm 15.18$ & $0.505^{* *}$ & 0.805 \\
\hline Illköğretim & 94 & 62.7 & $55.46 \pm 17.37$ & & \\
\hline Lise & 15 & 10 & $58.28 \pm 16.54$ & & \\
\hline Üniversite & 9 & 6 & $57.55 \pm 14.76$ & & \\
\hline \multicolumn{6}{|l|}{ Medeni durum } \\
\hline Evli & 135 & 90 & $56.10 \pm 17.16$ & $0.689^{*}$ & 0.759 \\
\hline Bekar & 15 & 10 & $56.41 \pm 14.88$ & & \\
\hline \multicolumn{6}{|l|}{ Çalışma durumu } \\
\hline Çalışıyor & 48 & 32 & $55.26 \pm 17.14$ & $2.315^{*}$ & 0.020 \\
\hline Çalışmıyor & 102 & 68 & $60.01 \pm 14.82$ & & \\
\hline \multicolumn{6}{|l|}{ Gelir gider durumu } \\
\hline Gelir giderden çok & 25 & 16.7 & $55.08 \pm 17.33$ & $0.762^{* *}$ & 0.467 \\
\hline Gelir gidere eşit & 83 & 55.3 & $56.42 \pm 16.38$ & & \\
\hline Gelir giderden az & 42 & 28 & $58.51 \pm 16.46$ & & \\
\hline \multicolumn{6}{|l|}{ NYHA evresi } \\
\hline Evre 1 & 33 & 22 & $53.10 \pm 19.68$ & $3.619^{* *}$ & $\begin{array}{c}0.014 \\
\text { Post hoc: } 2 \mathrm{vs} 4\end{array}$ \\
\hline Evre 2 & 51 & 34 & $52.06 \pm 14.99$ & & \\
\hline Evre 3 & 47 & 31.3 & $57.19 \pm 16.71$ & & \\
\hline Evre 4 & 19 & 12.7 & $60.50 \pm 14.84$ & & \\
\hline \multicolumn{6}{|l|}{$\begin{array}{l}\text { Ölüm kavramının kaygı } \\
\text { uyandırma durumu }\end{array}$} \\
\hline Evet & 83 & 55.3 & $64.00 \pm 14.57$ & $0.002^{*}$ & 0.001 \\
\hline Hayır & 67 & 44.7 & $48.00 \pm 14.47$ & & \\
\hline
\end{tabular}

n: katılımcı sayısı; NYHA: New York Heart Association; TPDAS: Thorson Powell Death Anxiety Scale (Thorson Powell Ölüm Kaygısı Ölçeği); *: independent sample t testi; **: One Way ANOVA.

komorbid hastalıklarına bakıldığında; \%78.7'sinde hipertansiyon, \%38'inde diabetes mellitüs, \%12'sinde böbrek yetersizliği, \%8'inde ise kronik obstrüktif akciğer hastalığı (KOAH) olduğu bulundu. Hastaların \%79.8' inin sigara içmediği ya da bıraktığı, \%75.7'sinin hiç alkol kullanmadığı, \%93'ünün ilaçlarını düzenliği kullandığı, \%62.7'sinin ise son bir yılda hastaneye ikiden fazla başvurduğu bulundu. Hastaların \%38.3'ü fiziksel sağlığını orta düzeyde, \%35'i ruhsal sağlığını orta düzeyde gördüğünü bildirdi.

Hastaların yarısından fazlası (\%55) ölüm kavramının endişe uyandırdığını ifade etti. KY tanısı almadan önce ölümle ilgili endişe duymayan hastalar ise büyük çoğunluğu (\%81.7) oluşturmaktadır. Hastaların ölüm kaygısı yaşamasına neden olan faktörleri, \%42'si yalnızlık korkusu, \%21'i yok olma korkusu, \%16.7'si cezalandırılma korkusu, \%5.3'ü denetimini yitirme korkusu, \%13.7'si ise belirsizlik korkusu olarak gördüğünü söyledi.

Thorson - Powel Ölüm Kaygısı Ölçeği'nden alınan puanlar değerlendirildiğinde; 65 yaş altındaki hastaların ölçek puan ortalaması $61.41 \pm 13.12$, 65 ve üstü yaş grubunda olan hastaların ise $55.42 \pm 17.04$ 'tür. Yaşa göre Thorson - Powel Ölüm Kaygısı Ölçeği ortalama puanları arasında anlamlı fark yoktur ( $p>0.05)$. Cinsiyete göre ölçek puan ortalamaları erkeklerde $56.70 \pm 17.90$ kadınlarda $56.91 \pm 14.76$ olarak bulundu. Cinsiyete göre Thorson - Powel Ölüm Kaygısı Ölçeği ortalama puanları açısından anlamlı fark bulunmadı ( $p>0.05$ ). Eğitim seviyesi okur yazar olmayanların ölçek puan ortalaması $56.84 \pm 15.18$, ilköğretim olanların $55.46 \pm 17.37$, lise olanların $58.28 \pm 16.54$, üniversite olanların ise $57.55 \pm 14.76$ olduğu bulundu. Eğitim seviyesine göre Thorson - Powel Ölüm Kaygısı Ölçeği ortalama puanları arasında anlamlı fark bulunmadı ( $p>0.05$ ). Evlilerin ölçek 
puan ortalaması $56.10 \pm 17.16$ ve bekarların $56.41 \pm 14.88$ olup Thorson - Powel Ölüm Kaygısı Ölçeği ortalama puanları arasında anlamlı fark yoktur ( $p>0.05)$. Çalışan hastaların ölçek puan ortalaması $55.26 \pm 17.14$ olup çalışmayan hastaların ise $60.01 \pm 14.82$ 'dir. Çalışmayan hastaların ölüm kaygısı çalışan hastalara göre daha yüksek olup aralarındaki farkın istatistiksel açıdan anlamlı olduğu bulundu $(p<0.05)$. Geliri giderinden çok olan hastaların ölçek ortalama puanı $55.08 \pm 17.33$, geliri giderine eşit olanların $56.42 \pm 16.38$ ve geliri giderinden az olanların $58.51 \pm 16.46$ 'dır. Gelir durumu ile Thorson - Powel Ölüm Kaygısı Ölçeği puanı arasında istatistiksel olarak anlamlı fark yoktur ( $p>0.05$ ). NYHA sınıflamasına göre KY hastalığı evresine bakacak olursak; ölçek puan ortalaması Evre 2 hastalarında en düşük (52.06 14.99) ve Evre 4 hastalarında ise en yüksek $(60.50 \pm 14.84)$ olduğu ve aralarında anlamlı fark olduğu bulundu $(p<0.05)$. Ölüm kavramının endişe uyandırdığını söyleyen hastaların ölçek puan ortalaması $(64.00 \pm 14.57)$ ölüm kavramını endişe olarak görmeyen hastaların puan ortalamasından (48.00 \pm 14.47$)$ daha yüksek ve istatistiksel açıdan ileri düzeyde anlamlıdır $(\mathrm{p}<0.001)$ (Tablo 1$)$.

\section{KY Hastalarının Thorson - Powel Ölüm Kaygısı Ölçeği Puan Ortalaması}

Thorson - Powel Ölüm Kaygısı Ölçeği'nde toplam 25 soru olup her biri 0-4 arasında puanlanmaktadır. Buna göre ölçekten en az 0 en yüksek 100 puan alınabilmektedir. Araştırmamıza katılan KY hastalarının Thorson - Powel Ölüm Kaygısı Ölçeği'nden aldığı en düşük puan 9 olup en yüksek puan ise 92'dir. Hastaların Thorson - Powel Ölüm Kaygısı Ölçeği puan ortalaması ise $56.80 \pm 16.55$ 'dir (Tablo 2).

\section{Tartışma}

KY artan yaşlı popülasyon ve tedavideki gelişmelerle birlikte mortalitesi ve morbiditesi yüksek kronik bir hastalıktır. Özellikle 65 yaş üstü bireylerde sık görülen ve ilerleyen evrelerinde daha sıklıkla semptom yaşanmasına neden olan, hastaneye başvuruları arttıran, ölüm oranı ve tedavi maliyeti yüksek bir hastalıktır. Yaşanan ağır semptomların ve tekrarlı yatışların $\mathrm{KY}$ hastalarında ölüm kaygısına neden olabileceği düşünülmektedir. Ölüm kaygısı depresyon ve anksiyete bozukluğu gibi KY hastalarının tedavi seyrini ve prognozunu önemli derecede etkilediğinden erken dönemde belirlenmesi önem arz etmektedir. Bu çalışmada, KY hastalarında psikososyal sorunların sebepleri arasında gösterilen ölüm kaygısnın belirlenmesi amaçlanmıştır. Araştırmamıza katılan KY hastalarının yaş ortalaması $66.53 \pm 9.072$ dir. Hastaların büyük çoğunluğu 65 yaş üstü (\%60.3) ve yarısından fazlası ise erkektir (55.3). KY yaşı ı popülasyonda özellikle 75 yaş üstü hastaların hastaneye yatırılma nedeni olarak bildirilmiştir. ${ }^{[15]}$ Başka bir çalışmada ise yüksek gelirli ülkelerde, KY 65 yaş ve üstü hastanede yatan yaşı hastalarda en sık görülen tanı olduğu bildirilmiştir. ${ }^{[15]} 40$ yaş altındaki bireyler için prevelans \%1 in altında, 80 yaşın üstünde ise $\% 10$ dur. Erkek ve kadınlar için risk $40-80$ yaş arasında \%20 dir. ${ }^{[15]}$ 1959-1999 yılları arasında yapılan Framingham çalışması ve 2015 yılında rapor edilen 2002-2010 yılları arasında yapılan Olmsted County kohort çalışmasına göre kadınlarda KY görülme oranı gözle görülür derecede büyük bir düşüşle azalırken, erkeklerde $K Y$ görülme oranı 2006 yılına kadar artış göstermiş ve son dört yılda ise minimal bir düşüşle sabit kalmaya devam etmiş̧ir. Yani 2006 yılından günümüze kadar erkek popülasyonda KY görülme oranı kadınlara göre daha fazladır. ${ }^{[17,18]}$ Türkiye'deki Kalp yetersizliği prevelansı ve öngörücüleri: HAPPY çalışmasına göre EF \%50'nin altında olan popülasyonda erkek cinsiyet, $\% 50$ 'nin üstünde olan popülasyonda ise kadın cinsiyet daha baskın bulunmuştur. HAPPY çalışmasına göre KY olan hastaların yaş ortalaması $61.1 \pm 10.6$, kadın cinsiyet \%49.2, eğitim düzeyi \%47.2 ile çoğunlukla ilköğretim, HT bulunma oranı \%73.3, diyabet oranı \%23.4, kronik böbrek yetersizliği oranı \%27.8 bulunmuştur. HAPPY çalışmasına göre risk faktörleri yönünden kadın cinsiyet daha riskli olmasına rağmen KY erkeklerde daha yüksek oranda görüldüğü bulunmuştur. ${ }^{[19]}$ Dünyada ve ülkemizde yapılan çalışmaların sonuçlarına göre bizim çalışmamıza katılan KY hastalarının sosyodemografik özellikleri benzerlik göstermektedir.

Çalışmamıza katılan KY hastalarının Thorson - Powel Ölüm Kaygısı Ölçeği' nden aldığı puan $56.80 \pm 16.55$ olup bu puan hastaların orta düzeyden biraz fazla ölüm kaygısı yaşadığını göstermektedir. Ayrıca 65 yaş altı bireylerde genel gurubun oldukça üzerinde bir ortalama puan ile orta seviyeden faz-

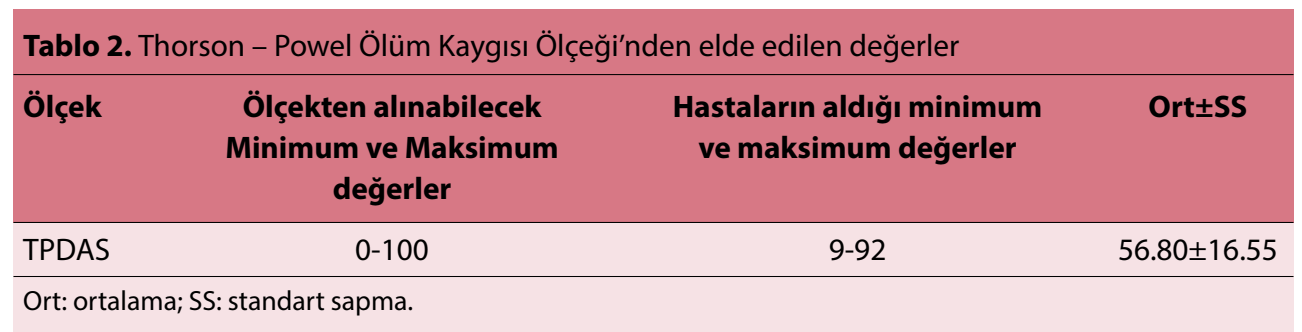


la ölüm kaygısı yaşadığı bulunmuştur. Çalışmamızda kadın ve erkeklerde ölüm kaygısı düzeyi hemen hemen aynı olup kadınlarda çok az bir farkla yüksek olduğu görüldü. Literatürde özellikle genç yaşta ve kadınlarda ölüm kaygısının yüksek olabileceği bildirilmiştir. ${ }^{[7,20]}$ Literatürde erkeklerde düşük endişe düzeylerinin, erkeklerin duygusal tepkileri bastırma veya önleme eğilimine bağlı olabileceği öne sürülmüş olup daha az ölüm kaygısı yaşayabilecekleri öngörülmektedir. ${ }^{[21]}$ Depaola ve ark. (2003)'nın yaşlı erişkinlerde ölüm kaygısı ve yaşlılara yönelik tutumu cinsiyet ve etnik köken faktörleri yönünden inceledikleri çalışmalarında da ölüm kaygısnın genç ve orta yıllarda yaşılara göre oldukça yüksek olduğu bildirilmiştir. ${ }^{[22]}$ Şahan ve ark. (2018)'nın ülkemizde yapmış olduğu miyokard infarktüsü (Mi) olan hastalarda ve kanserli hastalarda ölüm kaygısını belirledikleri çalışmada Mi geçirmiş hastaların kanser hastalarına göre daha yüksek düzeyde ölüm kaygısı yaşadığını bulmuş ve bunun nedenini aniden ve beklenmedik şekilde ölümle yüzleşmek olabileceği ifade edilmiştir. Şahan ve ark. (2018) Mi geçirmiş hastaların (yaş ortalaması 57.17 \pm 12.32 ; \%81.7 erkek) Thorson - Powel Ölüm Kaygısı Ölçeği puan ortalamasını $51.60 \pm 16.40$ olarak bulmuş olup hastaların orta düzeyde ölüm kaygısı yaşadığını bildirmişlerdir. Bu çalışmanın sonuçları ile bizim bulgularımız paralellik göstermektedir. [23] Öztürk ve ark. (2011) yapmış olduğu yaşlı bireylerde ölüm kaygısını inceledikleri çalışmada 60 yaş üstü bireyleri çalışmaya dahil etmişler ve çalışmaya katılan hastaların yaş ortalaması $67.16 \pm 5.0$ olup bizim çalışmamız bu çalışma ile benzerdir, aynı zamanda bireylerin Templerin Ölüm Kaygısı ölçeğinden aldıkları puan $7.7 \pm 3.8$ olup bizim çalışmamızda olduğu gibi bireylerin orta düzeyde ölüm kaygısı yaşadıkları söylenebilir. Bu çalışmada da erkek (7.58 \pm 3.7$)$ ve kadın (7.98 \pm 3.8$)$ bireylerin ölüm kaygısı puanları birbirine çok yakın olup kadınlarda çok az farkla ölüm kaygııının yüksek olduğu görülmüştür. Bu çalışmada $60-70$ ve 71-80 yaş grubundaki bireylerin ölüm kaygısı puanları karşılaştıııldığında anlamlı fark görülmezken her iki grubun da ölüm kaygısını orta düzeyde yaşadığını belirten bir puan aldıkları görülmektedir. ${ }^{[24]}$ Bizim çalışmamızın sonuçları yukarıdaki çaIışmalarla benzerlik göstermektedir. Yaş arttıkça ölüm kaygısındaki azalmanın sebebi, önceki yıllarda bireysel yaşam çatışmalarının çözümlerine, yaşam doyumu seviyelerindeki genel değişime ya da kişinin yaşam amacına yönelik algıların değişmesine bağlanabilir. Yaş arttıkça psikososyal olgunluğa erişmiş olmak da ölüm kaygısını azaltan diğer bir önemli belirteçtir. ${ }^{[25]}$ Çalışmamızda cinsiyetler arasında ölüm kaygısı puanları açısından istatistiksel bir fark görülmedi ve literatürdeki birçok çalışma ile paralellik göstermektedir. ${ }^{[22-24]}$ Ancak çok eski yıllarda yapılmış bazı çalış- maların sonuçlarına göre kadınların erkeklere göre ölüm kaygısı ölçümlerinde daha yüksek puan aldığı bildirilmiştir. [26, 27] Ölüm kaygısındaki cinsiyet farklılığını tespit eden araştırmaların çoğu, Templer'in (1970) Ölüm Kaygısı Ölçeğini kullandığı belirtilmiştir. Bu ölçeği kullanarak yapılan araştırmalar, kadın katılımcıların araştırmanın yapıldığı popülasyonun türüne bakılmaksızın ölüm kaygısı seviyelerini daha yüksek bulmuştur. ${ }^{[28]}$ Kadınların duygusal yönden erkeklere göre farklıııları olabileceği ve bunların kontrol edilerek bireylerin çalışmaya dahil edilmesi gerektiği söylenmektedir. ${ }^{[28]}$ Bununla birlikte, Fortner ve Neimeyer (1999) tarafından yürütülen bir meta analiz araştırma, cinsiyetin yaşlılarda ölüm kaygısının önemli bir göstergesi olmadığını ortaya koymuştur. ${ }^{[29]}$ Bizim çalışmamızda okur yazar olmayan ve ilköğretim seviyesinde öğrenim görenlerin lise ve üniversite seviyesinde eğitimi olan KY hastalarına göre ölüm kaygısı puanları daha düşük bulunmuş ancak anlamlı fark olmadığı görülmüştür. Şahan ve ark. (2018)'nın yaptıkları çalışmada ortaokul seviyesinde eğitimi olan hastaların ölüm kaygısını istatistiksel olarak anlamlı ve daha yüksek bulduklarını ifade etmişlerdir. ${ }^{[23]}$ Öztürk ve ark. (2011) da ilköğretim seviyesinde ve daha az öğrenim görmüş olanların ölüm kaygısı puanlarını lise mezunlarına göre daha yüksek ve istatistiksel açıdan anlamlı olduğunu bulmuştur. Bizim çalışmamızda eğitim seviyesi düşük olanlarda ölüm kaygısının daha düşük olmasını üniversite ve lise eğitimi olan hastaların yaş ortalamasının okuryazar olmayan ve ilköğretim seviyesinde öğrenim gören bireylerin olduğu gruptaki yaş ortalamasına göre daha düşük olduğu sonucuna bağlamaktayız. Çalışmamızın verilerine göre yaş arttıkça ölüm kaygısı da azalmaktadır, bizim çalışmamıza göre Şahan ve ark. (2018) ve Öztürk ve ark. (2011)'nın çalışmaları arasındaki farklılığın yaşla bağlantılı olduğunu söyleyebiliriz. Ayrıca literatürde eğitim seviyesinin artması ile iş yaşamının daha yoğun geçebileceği, günlük yaşamda da bireyin daha aktif olabileceği ve böylece ölümü hatırlama oranlarının daha düşük olabileceği gibi bizim çalışmamızın sonuçlarını destekleyen bilgiler vardır. ${ }^{[30]}$ Bizim çalışmamızın sonuçlarına göre medeni durum açısından evli ve bekar hastaların ölüm kaygısı puanları açısından bir fark bulunmadı. Şahan ve ark. (2018) ve Öztürk ve ark. (2011)'da yaptıkları çalışmalarda medeni durumun ölüm kaygısnı etkilemediğini bildirmişlerdir. ${ }^{[23,24]}$ Bizim çalışmamızda çalışmayan KY hastalarının çalışanlara göre ölüm kaygısı puanı anlamlı olarak daha yüksek olduğu bulundu. Şahan ve ark. (2018) da çalışmayan Mi geçirmiş hasta grubunun çalışan hastalara göre ölüm kaygısı puanlarını anlamlı olarak yüksek bulmuşlardır. [23] Öztürk ve ark. (2011) da çalışmalarında hiç çalışmamış bireylerin çalışıp emekli olmuş bireylere göre ölüm kaygısı 
puanını daha yüksek bulmuştur. ${ }^{[24]}$ Çalışma hayatı bireyin daha aktif ve sosyal olmasını sağladığı için psikososyal olgunlaşmaya faydası olduğu söylenebilir. Psikososyal olgunluk, olaylara bakış açısının farklılaşması, kendini tanıma ve olaylar karşısında çözümleme yeteneğinin artmasını sağlayabilir. Ölümün yaşamın gerçeği olduğunu bu olgunluğa erişmiş kişiler daha kolay kabul edebilir bu da ölüm kaygısını azaltabilir. Çalışmamızda NYHA evre 2 ile NYHA evre 4 grubundaki hastaların ölüm kaygısı puanları arasında anlamlı fark olduğu görüldü. NYHA evre 4 teki hastaların ölüm kaygısı daha yüksektir. $\mathrm{KY}^{\prime}$ nin ileri evrelerinde semptom yaşama sıklığı ve ağır semptomları yaşamaya bağlı hastanaye başvuruların artması ve yatışların tekrarlanması olasılığı yüksektir. NYHA evre $4 \mathrm{KY}$ hastaları istirahat durumunda bile nefes darlığı çekerler ve bu sebeplere bağlı ölüm kaygısnı daha fazla yaşayabilirler. Ayrıca bireylerde kendi ölümüne yakınlığını vurgulayan göze çarpan bir takım ipuçları görmesi (örn; KY hastalarının semptomlarını sık yaşamaya başlaması ve hastaneye başvurularının artması) ve bunlara devamlı maruz kalması ölüm kaygısını arttırabilir. Ölüm kavramının endişe uyandırdığı hastaların da ölüm kaygısını daha fazla yaşamasının altında yatan nedenler, hastaların ölüme yüklediği anlam, psikososyal olgunluk dereceleri ve önceki deneyimleri ile ilişkili olabileceği düşünülmektedir.

\section{Sonuç}

$\mathrm{Bu}$ araştırma, KY hastalarında ölüm kaygısının ve ölüm kaygısını etkileyen faktörlerin belirlenmesi ile ilgili bulguları içermektedir ve bu bulguların literatüre önemli katkılar sunacağı düşünülmektedir. Bu araştırmanın sonucunda, KY hastalarının ölüm kaygısı orta düzeyde bulundu. Çalışmayan hastaların, NYHA sınıflamasına göre evre 4'teki hastaların ve ölümü endişe uyandıran bir kavram olarak gören hastaların ölüm kaygısı yüksektir. KY hastalarında ölüm kaygısına neden olabilecek faktörlerin değerlendirilmesi ve ileride gelişebilecek psikososyal sorunların önüne geçilebilmesini hedefleyen tedavi yaklaşımları benimsenmelidir. KY olan daha büyük hasta gruplarıla, başka faktörlerin de ele alınarak ölüm kaygısı ile ilişkisinin incelendiği yeni çalışmaların yapılması önerilmektedir.

\section{Teşekkür}

Araştırmamızın yürütülmesine katkı sağlayan ve çalışmaya katılmayı içtenlikle kabul edip bilgilerini bizimle paylaşan tüm hastalara teşekkür ederiz.

Etik Kurul Onayı: Marmara Üniversitesi Sağlık Bilimleri Enstitüsü Klinik Araşsırmalar Etik Kurulu'ndan (Onay Tarihi ve Sayısı: 17.12.2018-235) etik kurulu izni ve kurum izni alınarak gerçekleştirildi.
Hakem Değerlendirmesi: Dış bağımsız.

Çıkar Çatışması: Yazarlar arasında herhangi bir çıkar çatışması bulunmamaktadır.

Yazarlık Katkıları: Konsept: B.B., S.O.; Dizayn: B.B., S.O.; Veri Toplama veya Iş̧leme: Z.K., S.Ç., C.K.; Analiz veya Yorumlama: B.B.; Literatür Arama: B.B.; Yazan: B.B.

\section{Kaynaklar}

1. Hunt SA. ACC/AHA 2005 guideline update for the diagnosis and management of chronic heart failure in the adult: a report of the American College of Cardiology/American Heart Association Task Force on Practice Guidelines (Writing Committee to Update the 2001 Guidelines for the Evaluation and Management of Heart Failure) J Am Coll Cardiol 2005;46:e1-e82.

2. Shah AB1, Morrissey RP, Baraghoush A, Bharadwaj P, Phan A, Hamilton M, Kobashigawa J, Schwarz ER. Failing the failing heart: a review of palliative care in heart failure. Rev Cardiovasc Med 2013;14(1):41-8.

3. Alpert CM, Smith MA, Hummel SL, and Hummel EK. Symptom burden in heart failure: assessment, impact on outcomes, and management. Heart Fail Rev. Heart Fail Rev 2017;22(1):25-39.

4. Evangelista LS, Lombardo D, Malik S, Ballard-Hernandez J, Motie M, Liao S. Examining the effects of an outpatient palliative care consultation on symptom burden, depression, and quality of life in patients with symptomatic heart failure. J Card Fail 2012;18(12):894-9.

5. Barnes S, Gott M, Payne S, Parker C, Seamark D, Gariballa S, Small N. Prevalence of symptoms in a community-based sample of heart failure patients. J Pain Symptom Manage 2006;32(3):208-16.

6. Adler ED, Goldfinger JZ, Kalman J, Park ME, Meier DE. Palliative care in the treatment of advanced heart failure. Circulation 2009;120(25):2597-606.

7. Frencha C, Greenauera N, Mellob C. A Multifactorial Approach to Predicting Death Anxiety: Assessing the Role of Religiosity, Susceptibility to Mortality Cues and Individual Differences. Journal of Social Work in End-of-Life\&Palliative Care 2017;13:151-172.

8. Rumsfeld JS, Havranek E, Masoudi FA, Peterson ED, Jones P, Tooley JF, Krumholz HM, Spertus JA. Depressive symptoms are the strongest predictors of short-term declines in health status in patients with heart failure. Cardiovascular Outcomes Research Consortium.J Am Coll Cardiol 2003;42(10):1811-7.

9. Celano CM, Villegas AC, Albanese AM, Gaggin HK, Huffman JC. Depression and Anxiety in Heart Failure: a Review. Harv Rev Psychiatry 2018;26(4):175-184.

10. Türk Kardiyoloji Derneği Kalp Yetersizliği Çalışma Grubu KY Bülteni. Kalp Yetersizliğinde Psikososyal Boyut 2015;4.

11. Lowey SE, Norton SA, Quinn JR, Quill TE. Living with advanced heart failure or COPD: experiences and goals of individuals nearing the end of life. Res Nurs Health 2013;36(4):349-58.

12. Rasmussen CA, Brems $C$. The relationship of death anxiety with age and psychosocial maturity. J Psychol 1996;130:141-144.

13. Thorson JA, Powell FC. A revised death anxiety scale. Death 
Stud 1992;507-521.

14. Karaca F, Yıldız M. Thorson-Powell Ölüm Kaygısı Ölçeğinin Türkçe Çevirisinin Normal Populasyonda Geçerlik ve Güvenirlik Çalışması.Tabula Rasa 2001;1:43-55.

15. Roth GA, Forouzanfar MH, Moran AE, Barber R, Nguyen G, Feigin VL, Naghavi M, Mensah GA, Murray CJ N. Demographic and epidemiologic drivers of global cardiovascular mortality. Engl J Med 2015; 372(14):1333-41.

16. Braunwald $\mathrm{E}$. The war against heart failure: the Lancet lecture. Lancet 2015;385:812-24.

17. Gerber $Y$, et al. A contemporary appraisal of the heart failure epidemic in Olmsted County, Minnesota, 2000 to 2010. JAMA Intern. Med 2015;175:996-1004.

18. Ziaeian B and Fonarow GC. Epidemiology and aetiology of heart failure Nat Rev Cardiol 2016;13(6):368-378.

19. Değertekin $M$, Erol Ç, Ergene $O$, Tokgözoğlu L, Aksoy M, Erol MK, Eren M, Şahin M, Eroğlu E, Mutlu B, Kozan Ö. Türkiye' deki kalp yetersizliği prevelansı ve öngörüdürücüleri: HAPPY çalışması. Türk Kardiyol Dern Arş 2012;40(4):298-308.

20. Henrie J, \& Patrick JH. Religiousness, religious doubt, and death anxiety. Inter-national Journal of Aging and Human Development 2014;78:203-227.

21. Neimeyer RA, Currier JM, Coleman R, Tomer A, Samuel E. Confronting suffering and death at the end of life: The impact of religiosity, psychosocial factors, and life regret among hospice patients. Death Studies 2011;35:777-800.

22. DePaola SJ, Griffin M, Young JR, Neimeyer RA. Death anxiety and attitudes toward the elderly among older adults: The role of gender and ethnicity. Death Studies 2003;27:335-354.

23. Şahan E, Eroğlu MZ, Karataş MB, Mutluer B, Uğurpala C, Berkol TD. Death anxiety in patients with myocardial infarction or cancer. The Egyptian Heart Journal 2018;70:143-147.

24. Öztürk Z, Karakuş G, Tamam L. Yaşıı bireylerde ölüm kaygısı. Anadolu Psikiyatri Dergisi 2011;12:37-43.

25. Fortner V, Robert A, Neimeyer B. Death anxiety in older adults: a quantitative review. Death Stud 1999;23:387-411.

26. Neimeyer RA. The threat hypothesis: A conceptual and empirical defense. Death Studies 1986;10:177-190.

27. Ridgon MA, Epting FR. Reduction in deaththreat as abasis for optimal functioning. Death Studies 1985;9:427-448.

28. Neimeyer RA. Death anxietyand attitudes toward the elderly among older adults:the role of gender and ethnicity. Death Studies 2003;27:335-354.

29. Fortner BV, Neimeyer RA. Death anxiety in older adults: A quantitative review. Death Studies 1999;23:387-407.

30. Erdogdu MY, Özkan M. Farklı dini inanışlardaki bireylerin ölüm kaygıları ile ruhsal belirtiler ve sosyo-demografik degiskenler arasındaki iliskiler. Turgut Özal Tıp Merk Derg 2007;14. 